\title{
Lower extremity arterial disease in patients with diabetes: a contemporary narrative review
}

\author{
Mathilde Nativel ${ }^{1}$, Louis Potier 2,3,4, Laure Alexandre 1,5, Laurence Baillet-Blanco ${ }^{1}$, Eric Ducasse ${ }^{5,6}$, Gilberto Velho ${ }^{4}$, \\ Michel Marre ${ }^{2,3,4,7}$, Ronan Roussel ${ }^{2,3,4}$, Vincent Rigalleau ${ }^{1,5}$ and Kamel Mohammedi ${ }^{1,5^{*}}$ (D)
}

\begin{abstract}
Lower-extremity arterial disease (LEAD) is a major endemic disease with an alarming increased prevalence worldwide. It is a common and severe condition with excess risk of major cardiovascular events and death. It also leads to a high rate of lower-limb adverse events and non-traumatic amputation. The American Diabetes Association recommends a widespread medical history and clinical examination to screen for LEAD. The ankle brachial index (ABI) is the first non-invasive tool recommended to diagnose LEAD although its variable performance in patients with diabetes. The performance of $A B I$ is particularly affected by the presence of peripheral neuropathy, medial arterial calcification, and incompressible arteries. There is no strong evidence today to support an alternative test for LEAD diagnosis in these conditions. The management of LEAD requires a strict control of cardiovascular risk factors including diabetes, hypertension, and dyslipidaemia. The benefit of intensive versus standard glucose control on the risk of LEAD has not been clearly established. Antihypertensive, lipid-lowering, and antiplatelet agents are obviously worthfull to reduce major cardiovascular adverse events, but few randomised controlled trials (RCTs) have evaluated the benefits of these treatments in terms of LEAD and its related adverse events. Smoking cessation, physical activity, supervised walking rehabilitation and healthy diet are also crucial in LEAD management. Several advances have been achieved in endovascular and surgical revascularization procedures, with obvious improvement in LEAD management. The revascularization strategy should take into account several factors including anatomical localizations of lesions, medical history of each patients and operator experience. Further studies, especially RCTs, are needed to evaluate the interest of different therapeutic strategies on the occurrence and progression of LEAD and its related adverse events in patients with diabetes.
\end{abstract}

Keywords: Ankle-brachial index, Atherosclerosis, Diabetes mellitus, Intermittent claudication, Lower-extremity arterial disease, Peripheral arterial disease, Revascularization

\section{Introduction}

Lower extremity arterial disease (LEAD) is a major manifestation of systemic atherosclerosis with severe associated cardiovascular, lower limb and functional complications. It results from a partial or complete obstruction of one or more lower limb arteries. The first known presentation of lower-limb vascular disease was

\footnotetext{
*Correspondence: km.mmohammedi@gmail.com

${ }^{1}$ Département d'Endocrinologie, Diabétologie, Nutrition, Hôpital Haut-

Lévêque, Avenue de Magellan, 33604 Pessac Cedex, France

Full list of author information is available at the end of the article
}

reported in 1831 in a horse that had a lameness thought to be due to femoral artery occlusion of the posterior limb. Similar symptom was described few years later in humans and characterized as an intermittent claudication (IC). Further investigations showed that IC was linked to muscle ischemia, induced by walking, and considered it as a clinical manifestation of LEAD. During the last decades, a large body of data have reported that LEAD was associated with increased risk of non-traumatic lower limb amputation (LLA), cardiovascular disease (CVD), and mortality [1-3]. Nowadays, LEAD has become an 
emerging public health burden with an endemic progression worldwide resulting from a demographic expansion, population aging and increasing prevalence of tobacco smoking habits, hypertension, dyslipidaemia, and type 2 diabetes [4-6]. Yet, LEAD is particularly frequent in diabetic patients with worse outcomes, especially the risk of LLA, four to five times higher, compared with non-diabetic subjects [1, 2, 7-9]. Despite its severity, LEAD remains less studied than other diabetic vascular complications; and only few randomised controlled trials (RCTs) have dealt with major lower-limb adverseevents as pre-specified endpoints. Therefore, widespread reviews of the literature dedicated to LEAD are scarce, especially in people with diabetes. We present here a comprehensive narrative review of the available literature to describe and synthesize epidemiology, pathophysiology, screening, diagnosis, and therapeutics of LEAD in patients with diabetes.

\section{Epidemiology and risk factors Prevalence and incidence}

LEAD affects over 200 millions people worldwide, including 40 millions living in Europe [5]. It is 2-4 times more frequent in people with type 2 diabetes than in the general population $[3,4]$. The prevalence of LEAD varies across studies depending to differences in characteristics of the populations including LEAD definition, age, and ethnicity. Usually discovered during the 5th decade of life, the prevalence of LEAD increased exponentially after 65 years of age. In the Action in Diabetes and Vascular Disease: PreterAx and DiamicroN Modified-Release Controlled Evaluation (ADVANCE) trial, the baseline prevalence of LEAD (defined as lower-limb amputation of at least one digit, chronic foot ulceration due to arterial insufficiency, or peripheral revascularization procedure) was estimated at $4.6 \%$ [10]. The LEAD prevalence was much higher and may exceed $20 \%$ when its definition was based on abnormal ankle-brachial index (ABI) [2, 4, 11]. The prevalence increases also with rising duration of diabetes as shown in the UK Prospective Diabetes Study (UKPDS): $1.2 \%$ at diagnosis of diabetes and $12.5 \%$ after 18 years of its evolution [12]. In the same manner, different LEAD incidences were reported: 1.2 per 100 patientyears in ADVANCE trial and 3.7 per 100 patient-years in an Australian cohort $[2,13]$.

\section{Prognostic and risk factors}

LEAD is one of the major causes of diabetic foot. It was present in $49 \%$ of patients with diabetic foot in the EURODIALE study, and one-third of participants had both LEAD and infection [14]. Diabetic patients with LEAD, compared with those without LEAD, have also a higher risk of CVD, and cardiovascular and all-cause mortality $[2,10,11,15]$. The key risk factors are similar to those related to CVD, including age, sex, tobacco smoking, systolic blood pressure, and plasma concentrations of lipids $[12,13,16]$. A recent study has suggested that the leg fat distribution may be used as a potential marker for predicting CVD [17].

Microvascular disease, mainly macroalbuminuria and diabetic retinopathy, have been shown to be independent risk factors for LEAD [13, 16]. Furthermore, a recent large epidemiological study has shown that low glomerular filtration rate and pathological albuminuria were independently associated with excess risk of LEAD [18]. The risk of LEAD may also vary according to differences in region of origin. In ADVANCE study, the incidence of major LEAD was lesser in Asians compared with participants from Eastern Europe or Established Market economies [13]. Despite a higher rate of CVD, people from South Asia, compared with white Europeans, have a lower prevalence of LEAD [19]. The explanation of this paradox has not yet been clearly elucidated, and genetic predisposition to LEAD may be suspected.

\section{Pathophysiological mechanisms}

Intermittent claudication results from a diminished inflow of oxygen due to a reduced blood flow in the lower limbs during physical activity, which is a consequence of stenosis or obstruction of an artery irrigating the skeletal muscle [20]. Many mechanisms contribute to the development of LEAD, in particular arterial stiffness, thrombotic abnormalities, low-grade inflammation, advanced glycation end-products, and oxidative stress (Fig. 1) [21-23]. Several studies have suggested the development of an acute inflammatory reaction in response to ischemia induced by exercise, with increased release of different biomarkers (thromboxane, interleukin 8, intercellular adhesion molecules, or von Willebrand factor) and vasoconstrictors including endothelin-1 [24]. We have recently reported an independent association between plasma concentrations of tumor necrosis factor- $\alpha$ receptor 1 (TNRF1) and ischemiamodified albumin, inflammatory and redox status biomarkers, and an excess-risk of major LEAD in patients with type 2 diabetes [25]. Interestingly, TNFR1 improves the prediction of LEAD over the traditional risk factors.

Endothelial cells play an important role in vascular biology based on their strategic location between blood and tissues. They secrete many paracrine factors in the vascular wall and its lumen. In pathological setting, endothelial dysfunction induces structural, hemodynamic, and functional vascular abnormalities, altering blood vessels reactivity and relaxation, and generating atherosclerosis [26]. Endothelial dysfunction and increased arterial wall stiffness play an important role in the pathogenesis of LEAD in individuals with diabetes $[27,28]$. 


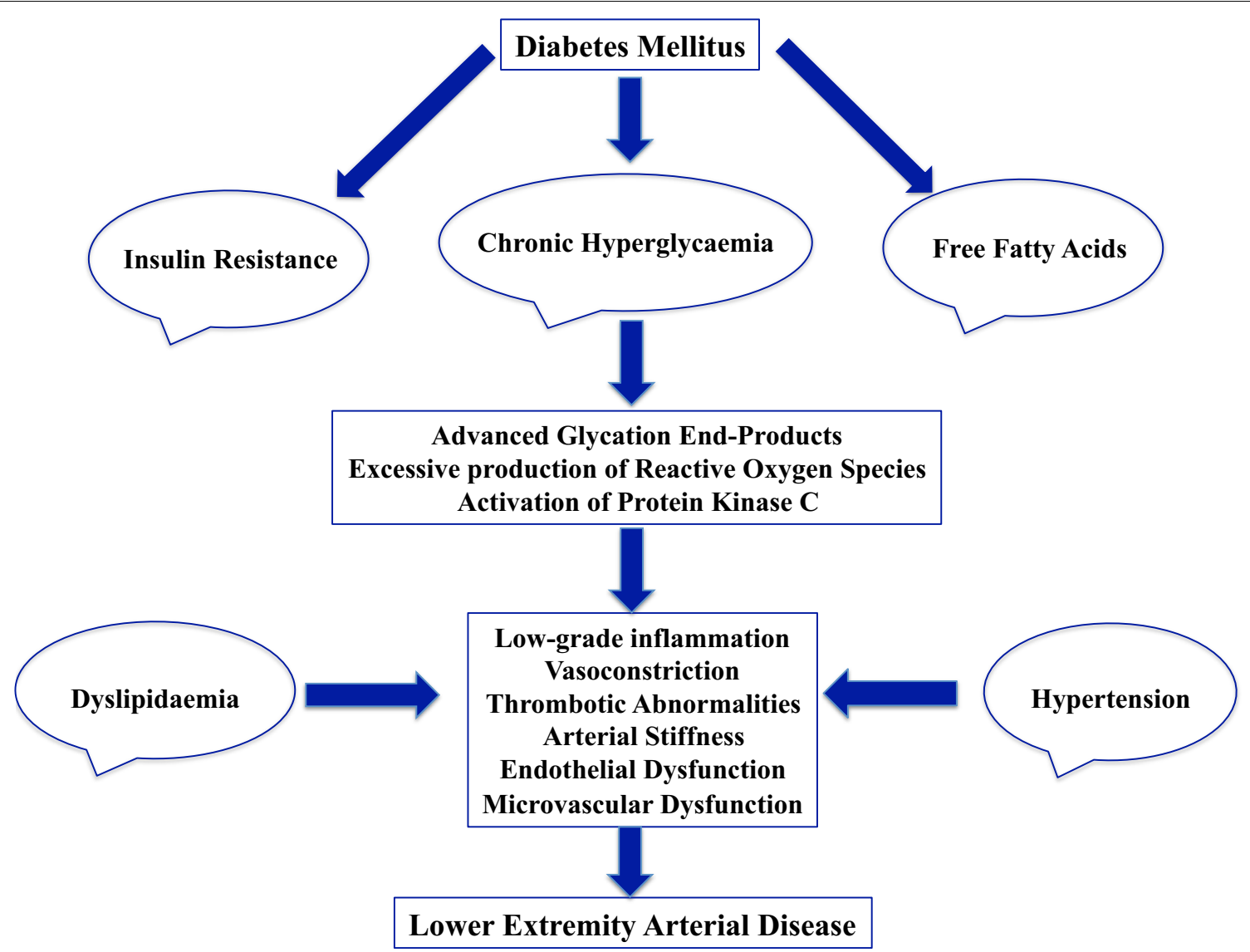

Fig. 1 Principal mechanisms involved in the pathogenesis of lower-extremity artery disease in patients with diabetes

LEAD has clearly been identified as a common manifestation of atherosclerosis of the large vessels [29]. However, recent studies provided evidence for the implication of microvascular dysfunction in the pathogenesis of macrovascular disease including LEAD [30-32]. An Italian study has shown microvascular histological changes including expansion of the basal membrane and a reduced capillary density in neuro-ischaemic diabetic feet with revascularization requirement [32]. In the ADVANCE study, the baseline history of microvascular disease (defined as the presence of macroalbuminuria (urinary albumin to creatinine ratio $>300 \mathrm{mg} / \mathrm{g}$ ), requirement of retinal photocoagulation therapy, proliferative retinopathy, macular oedema, or diabetes-related blindness) was independently associated with excess risk of major LEAD during follow-up [13]. Interestingly, microvascular disease was associated with distal LEAD manifestations (lower-limb ulceration or amputation induced by vascular disease) whereas macrovascular disease (defined as the presence of myocardial infarction, stroke, coronary artery bypass graft, percutaneous transluminal coronary angioplasty, or hospital admission for unstable angina or transient ischaemic attack) was linked to proximal presentation (requirement of peripheral revascularization). On the other hand, the baseline history of LEAD was associated with increased risk of advanced diabetic retinopathy, but not with the incidence of end-stage renal disease [10]. Patients with both major LEAD and chronic kidney disease (CKD) may have died before experiencing more advanced kidney endpoints. Of note, a previous study has reported a very high rate $(70-80 \%)$ of death during 4 years of follow-up in individuals with both LEAD and severe CKD [33].

\section{Screening and diagnosis}

\section{Clinical examination}

The American Diabetes Association (ADA) recommends (Table 1) an initial screening for LEAD based on an exhaustive interview and a clinical examination including a history of decreased walking speed, leg fatigue, claudication, and the palpation of the pedal pulses [34]. 
Diabetic neuropathy may hide symptoms of LEAD, and should be systematically screened as well. Distal diabetic neuropathy is also involved in medial arterial calcification that leads to incompressible arteries [35, 36]. The clinical presentation of LEAD can be assessed according to Lerich and Fontaine or Rutherford classification [37]. IC and rest pain are the most important signs to be evaluated, though they can be lacking or difficult to attribute exclusively to LEAD. Any deterioration of walking quality or speed must be taken into account as well as fatigue, pain, cramps, discomfort or burns in buttocks, thighs, calfs or feet. Those symptoms are especially suggestive of LEAD when triggered by exercise and quickly relieved with rest. The clinical examination may also contain a careful evaluation of the general aspect of the skin, hairiness, and lower limb temperature. Pulse palpation (distal pedis, posterior tibial, popliteal and femoral arteries), a simple and cheap clinical examination, should be systematically performed in all patients with diabetes [34]. Nonetheless, pulse palpation is not a reliable test; it depends on anatomic variations, physician experience, and examination conditions [38, 39]. Pulse palpation has a weak diagnostic performance [40-42], particularly the dorsal pedis pulse, which can be absent without any vascular abnormalities. However, the absence of both distal pedis and tibial posterior pulses during satisfying exam conditions improve the performance $[38,43]$.

\section{Ankle-brachial index testing}

Ankle-brachial index has emerged as the relatively simple, non-invasive, and inexpensive tool for LEAD diagnosis [44]. The ADA recommends the assessment of ABI as a first line non-invasive test in patients with symptoms or signs of LEAD [34]. It is computed as a ratio of systolic blood pressure at the ankle to the systolic blood pressure in the upper arm. ABI is normal in 1.0-1.4 range, suspicious in $0.9-1$ range, and obviously pathologic under 0.9. An ABI over than 1.4 is also considered as abnormal, reflecting calcified and stiffed arteries. ABI was also reported as a marker of CVD and death [45], but the latest US Preventive Services Task Force (USPSTF) recommendation (Table 1) has underlined the lack of evidence supporting the ABI use to screen for LEAD and cardiovascular risk in asymptomatic adult people [46]. The performance of ABI for LEAD screening is particularly inconsistent in people with diabetes $[47,48]$. A comprehensive systematic review showed a variable performance: the sensitivity of $\mathrm{ABI}<0.9$ ranged from 29 to $95 \%$ (median at $63 \%$ ), and its specificity varied between 58 and 97\% (median 93\%). The addition of $\mathrm{ABI}>1.3$ did not improve the discrimination. The measurement of ABI is also dependent on operator skills [49]. The performance is particularly affected by the presence of peripheral diabetic neuropathy, medial arterial calcification, and incompressible arteries. In these situations, the toe brachial index may be more effective (pathological if $<0.70$ ). The quality of studies evaluating alternative diagnostic techniques for the screening of LEAD in individuals with diabetes is poor. Otherwise, the toe pressure and the transcutaneous pressure of oxygen (TcPO2) are recommended for the diagnosis of lower limb critical ischemia (see below), and the estimation of the likelihood of wound healing or a requirement of amputation.

\section{Ultrasound and other imaging methods}

The Doppler ultrasound exam is an imaging method with a good LEAD diagnosis performance (sensitivity $93 \%$ and specificity 97\%) [50]. It is a simple, non-invasive, and an affordable method allowing anatomical and hemodynamic vascular assessments, regardless of medial arterial calcifications, but it remains dependent on the operator experience. The Doppler waveform analysis provides further information; a triphasic waveform reflects a normal hemodynamic state and then the absence of LEAD. The presence of monophasic or biphasic waveforms has a good negative predictive value but her positive predictive value remains less consistent depending on the presence of peripheral neuropathy [51]. Interestingly, a previous

Table 1 Publications of the major international guidelines in screening, diagnosis, and treatment of lower-extremity artery disease

\begin{tabular}{|c|c|c|c|c|}
\hline Society & Guidance & Journal & Year & References \\
\hline American Diabetes Association & Microvascular complications and foot care: standards of medical care in diabetes & Diabetes Care & 2018 & {$[34]$} \\
\hline US Preventive Services Task Force & $\begin{array}{l}\text { Screening for peripheral artery disease and cardiovascular disease risk assess- } \\
\text { ment with the ankle-brachial index }\end{array}$ & JAMA & 2018 & {$[46]$} \\
\hline $\begin{array}{l}\text { American Heart Association \& } \\
\text { American College of Cardiol- } \\
\text { ogy }\end{array}$ & Management of patients with lower extremity peripheral artery disease & Circulation & 2017 & {$[84]$} \\
\hline $\begin{array}{l}\text { European Society of cardiology \& } \\
\text { European Society for Vascular } \\
\text { Surgery }\end{array}$ & Diagnosis and treatment of peripheral arterial diseases & Eur Heart J & 2018 & {$[90]$} \\
\hline
\end{tabular}


study has shown that a semiquantitative score based on the ultrasonographic features of the lower limb arteries may help in the assessment of LEAD across different stages, as well as the evaluation of its associated cardiovascular risk [52]. A recent finding suggested that this score might be better than ABI to screen LEAD [53].

The computed tomography angiography, magnetic resonance angiography and angiography permit a precise topographic diagnosis and are often performed in the pre-operative work-up when large arterial vessels are involved. The topography of LEAD is usually categorized as proximal (from the common iliac to the superficial femoral artery) and distal lesions (from the popliteal to the dorsal pedis artery). The distal localisation has been shown to be more common than the proximal one in patients with diabetes [54].

\section{Critical limb ischemia}

The critical limb ischemia (CLI) is defined as the presence of ischaemic chronic rest pain ( $>2$ weeks) typically in the forefoot with or without ischaemic lesions or gangrene due to arterial occlusive disease. It is considered as the last stage of LEAD spectrum, with excessively high risk for CVD and death [55]. The CLI is frequent in patients with diabetes, and it may be suspected even in the absence of pain in patients with peripheral diabetic neuropathy. The diagnosis of CLI is confirmed based on one of the following: $\mathrm{ABI}<0.4$, ankle pressure $<50 \mathrm{mmHg}$, toe pressure $<30 \mathrm{mmHg}$ or $\mathrm{TcPO} 2<30 \mathrm{mmHg}$. Acute limb ischemia, an emergency condition, needs an urgent diagnosis to evaluate the odds of the limb salvage and to determine the requirement of medical and surgical treatments. The wound ischemia and foot infection (WIFI) classification has been recently recommended by the society of vascular surgery (SVS); it provides a risk stratification based on the severity of the wound, ischemia, and foot infection [56].

\section{Therapeutic strategies}

The management of LEAD in patients with diabetes requires a multidisciplinary team including endocrinologist, vascular surgeon, infectious disease specialist, radiologist, rehabilitation doctor, nurse, and podiatrist. Despite the high macrovascular risk, the based-evidence prevention therapies remain underused in diabetic patients with LEAD compared to their counterparts with coronary or cerebrovascular disease $[57,58]$. Therefore, a considerable proportion of patients with diabetes and LEAD remain at increased risk for CVD as well as overall adverse events [2]. A strict control of cardiovascular risk factors is crucial to manage LEAD, and to improve the cardiovascular and the overall prognosis of each patient.

\section{Anti-diabetic treatment}

\section{Intensive versus standard glucose control}

Epidemiological studies and RCTs showed the efficiency of intensive blood glucose control in the reduction of the development and progression of long-term microvascular complications (diabetic nephropathy, retinopathy, and neuropathy) in patients with diabetes [59-61]. However, the benefit of intensive glucose control in the prevention of CVD and death has not been clearly established, and its effect on the risk of LEAD has been rarely addressed in the literature. In the UKPDS trial, each 1\% reduction in HbA1c was associated with a $43 \%$ decreased risk of major LEAD (amputation or death following a peripheral vascular event) [62]. However, this benefit did not persist during the post-trial observational period of the UKPDS study [63]. In the ADVANCE trial, the incidence of major LEAD (lower-limb ulceration, amputation, revascularization requirement, or death induced by peripheral arterial disease) was comparable among randomized study arms (intensive versus standard glucose control) [13, 61]. A recent systematic review and meta-analyses (with a low level of evidence) displayed 35\% reduction of LLA risk in patients with type 2 diabetes assigned to intensive glycaemic control compared with those assigned to less intensive strategy, but no effect was observed on ischemic disease [64].

\section{Insulin-sensitizing versus insulin-providing therapy}

The PROspective pioglitAzone Clinical Trial In macroVascular Events (PROactive) trial showed a non-significant association between use of pioglitazone, an agonist of peroxisome proliferator-activated receptor $\gamma$ (PPAR $\gamma)$, and a higher risk of leg revascularization, compared with placebo [65]. However, the post hoc analyses of the Bypass Angioplasty Revascularization Investigation in Type 2 Diabetes (BARI-2D) trial displayed lower incidence of LEAD (new low $A B I \leq 0.9$, lower-extremity revascularization or LLA) among patients assigned to insulin-sensitizing therapy (metformin or thiazolidinedione) compared with those assigned to insulin-providing therapy (sulfonylureas, repaglinide, nateglinide or insulin) [66]. Furthermore, another observational study has shown that the use of metformin was associated with a lower prevalence of below-the-knee arterial calcification [67].

\section{New anti-diabetic agents}

After concerns about the cardiovascular safety of some anti-diabetic drugs, the US Food and Drug Administration (FDA) implemented a guidance statement in 2008 recommending cardiovascular safety trial of each new anti-diabetic agent. Thus, several RCTs were conducted worldwide and demonstrated the non-inferiority of 
some new inhibitors of dipeptidyl peptidase 4 (DPP-4) or glucagon-like peptide-1 (GLP-1) receptor agonists, compared with placebo in patients with type 2 diabetes [68-71]. Interestingly, other trials have shown cardiovascular benefit of some GLP-1 receptor agonists (liraglutide, semaglutide, and albiglutide) or sodium glucose co-transporter 2 (SGLT2) inhibitors (empagliflozin and canagliflozin) [72-76]. In contrast to cardiovascular and cerebrovascular endpoints, LEAD was not fully investigated in these studies. Although, Marso et al. reported in the SUSTAIN-6 trial, that participants treated by semaglutide, a prolonged action GLP-1 receptor agonist, had a significant $35 \%$ lower risk of coronary and peripheral revascularization, but with no specific data dedicated to lower-limb procedures [73]. A recent post hoc analysis of the liraglutide effect and action in diabetes: evaluation of cardiovascular outcome results (LEADER) trial displayed a fewer LLA rate among patients with diabetic foot assigned to liraglutide, compared with those assigned to placebo [77]. This difference seemed to be driven mainly by major amputation rather than minor amputation, but there was no difference between study arms in diabetic foot requiring peripheral revascularization. The incidence of LEAD was similar among study arms (exenatide versus placebo) in the Exenatide Study of Cardiovascular Event Lowering (EXCEL) trial [78]. Notably, the Canagliflozin Cardiovascular Assessment Study (CANVAS) trial has shown a twofold higher risk of LLA in participants assigned to canagliflozin, compared with those assigned to placebo [75]. This increased risk of amputation has been mainly driven by vascular disease, while the rate of diabetic neuropathy seemed to be lower in the canagliflozin group than in the placebo arm (CANVAS Program Collaborative Group, the 53rd Annual Meeting of the European Association for the Study of Diabetes, Lisbon, 15 September 2017; https://www.easd.org/programmeglance.html). The pathophysiological mechanisms likely to explain the high risk of LLA associated with canagliflozin in the CANVAS trial have not yet been established. It remains unclear if the risk of amputation is a class effect for all SGLT-2 inhibitors. While some studies suggested association with different SGLT-2 inhibitors and increased risk of LLA [79-81], the secondary analyses of the EMPA-REG OUTCOME trial have shown a similar incidence of LLA in empagliflozin versus placebo group [82]. Furthermore, a recent large real-life study conducted in the USA did not show association between SGLT2 inhibitors and the risk of LLA [83].

\section{Antihypertensive drugs}

The American Heart Association (AHA) and the American College of Cardiology (ACC) recommend antihypertensive treatment in patients with LEAD to decrease cardiovascular events and stroke (Table 1) [84], but the benefit-risk of each antihypertensive class in term of LEAD-related events has not yet been fully investigated even in the general population [85]. The relationship between blood pressure and LEAD is not simple, and may be U-shaped in the general population [86]. In the type 2 diabetes setting, the risk of LEAD increased with rising systolic blood pressure and decreasing diastolic blood pressure, and is particularly associated with growing pulse pressure [13], which is known as a surrogate of arterial stiffness [87]. Interestingly, each $10 \mathrm{mmHg}$ decrease of systolic blood pressure was associated with $16 \%$ reduction of LEAD risk in the observational period of the UKPDS study [88]. The post hoc analyses of the Veterans Affairs Diabetes (VADT) trial have also shown a reduction of the ischemic LLA rate in participants with systolic blood pressure $<140$ versus $\geq 140 \mathrm{mmHg}$ [89]. However, the ADVANCE trial has not reported any LEAD benefit related to perindopril/indapamide treatment, compared with placebo [13].

\section{Lipid lowering drugs \\ Statin therapy}

The European Society of Cardiology (ESC) and the European Society for Vascular Surgery (ESVS) recommended targeting serum low-density lipoprotein cholesterol (LDL-C) less than $1.8 \mathrm{mmol} / \mathrm{L}(<70 \mathrm{mg} / \mathrm{dL})$ or decreased by $\geq 50 \%$ if the initial value is between 1.8 and $3.5 \mathrm{mmol} / \mathrm{L}$ (70 and $135 \mathrm{mg} / \mathrm{dL}$ ) for all patients with LEAD (Table 1) [90]. Although the lack of specific evaluations of the effects of lipid-lowering drugs on the occurrence of LEAD-related endpoints, observational studies and few RCTs provide evidence for reductions of cardiovascular events and all-cause mortality in patients using statins [91-93]. In the Reduction of Atherothrombosis for Continued Health (REACH) registry, statin use was associated with a $17 \%$ decrease in adverse cardiovascular events rates among individuals with LEAD, without heterogeneity regarding diabetes status [94]. Other studies have also suggested that statin may reduce the LLA incidence and improve walking distance in patients suffering for IC [95-98].

\section{Fibrate therapy}

The use of Fenofibrate failed to reduce macrovascular events in participants with type 2 diabetes in the Action to Control Cardiovascular Risk in Diabetes (ACCORD) and the Fenofibrate Intervention and Event Lowering in Diabetes (FIELD) trials [99, 100]. However, secondary analyses of the FIELD trial displayed a 36\% reduction in the risk of LLA (a pre-specified tertiary endpoint) in participants assigned to fenofibrate, compared with those assigned to placebo [101]. This protection has been 
especially driven by decreased risk of minor amputation without known large-vessel disease rather than amputation with large-vessel lesions.

\section{PCSK9 inhibitors}

Despite the availability of effective drug therapies that reduce LDL-cholesterol, CVD remains an important cause of mortality and morbidity. Therefore, additional LDL-cholesterol reduction may be warranted, especially for patients who are unresponsive to, or unable to take, existing LDL-cholesterol reducing therapies. Proprotein convertase subtilisin/kexin type 9 (PCSK9) is a serin protease with effect on the LDL receptor cycle leading to its degradation and therefore inhibition of continuing LDLcholesterol clearance from the blood. This path is the target of newly developed lipid-lowering drugs, PCSK9 inhibitors, monoclonal antibodies leading to further LDLcholesterol decrease, with reducing CVD risk, but not cardiovascular or all-cause mortality [102]. The Further Cardiovascular Outcomes Research with PCSK9 Inhibition in Subjects with Elevated Risk (FOURIER) trial has shown that evolocumab, versus placebo, reduced LDLcholesterol and adverse cardiovascular events among patients with elevated cardiovascular risk on statin therapy [103]. Evolocumab decreased cardiovascular endpoints reliably in participants with and without diabetes at baseline [104]. The use of Evolocumab was also associated with $42 \%$ reduction of LEAD-related events (acute limb ischemia, major amputation, or urgent peripheral revascularization for ischemia) with consistent effects in those with or without known LEAD at baseline [105]. There was a consistent relationship between lower achieved LDLcholesterol and reduced risk of LEAD-related events.

\section{Antiplatelet and anticoagulation therapies Antiplatelet therapy in symptomatic or asymptomatic LEAD}

Antiplatelet drugs are advised in all patients with symptomatic LEAD or having undergone previous vascular revascularization, to reduce both CVD and peripheral vascular event. The ESC and the ESVS guidelines did not recommend antiplatelet therapy in subjects with asymptomatic LEAD (Table 1) [90]. In the general population, aspirin, compared with placebo, did not reduce vascular events among participants with asymptomatic LEAD [106]. Furthermore, the prevention of progression of arterial disease and diabetes (POPADAD) trial did not provide evidence to support the use of aspirin or antioxidant agents in the primary prevention of macrovascular events (including amputation above the ankle for critical limb ischaemia) in 1276 diabetic patients with asymptomatic LEAD [107].

\section{Single antiplatelet therapy}

The meta-analyses from the Antithrombotic Trialists Collaboration group showed that aspirin (or another oral antiplatelet drug) was protective in different high vascular risk populations, including those with LEAD [108]. However, some data might encourage the use of clopidogrel rather than aspirin in LEAD condition, especially in people with diabetes. A meta-analysis of 18 RCTs comparing aspirin to placebo in 5269 patients with symptomatic or asymptomatic LEAD did not show a significant reduction in cardiovascular adverse events, except for non-fatal stroke considered individually as a secondary endpoint [109]. No significant association was observed between aspirin treatment and the other secondary outcomes including all-cause or cardiovascular mortality, myocardial infarction, or major bleeding. The aspirin in patients at risk of ischaemic events (CAPRIE) trial, involving 20\% of participants with diabetes, has displayed reduction of the risk of LEAD-related events in participants assigned to clopidogrel $75 \mathrm{mg}$ compared with those assigned to aspirin $325 \mathrm{mg}$ [110]. Finally, treatment by Ticagrelor (90 mg twice daily) has not been shown to be superior to clopidogrel (75 mg once daily) for the reduction of cardiovascular or limb events in 13,885 participants (38\% of whom had diabetes) with symptomatic LEAD [111].

\section{Dual antiplatelet therapy}

No evidence exists for any benefit related to a dual antiplatelet therapy in patients with LEAD. In the post hoc analyses of the Clopidogrel for High Atherothrombotic Risk and Ischemic Stabilization, Management, and Avoidance (CHARISMA) trial, dual therapy (clopidogrel and aspirin) did not provide further vascular protection over aspirin alone in LEAD patients (36\% with diabetes), except for the risk of myocardial infarction and hospitalization for ischaemic events [112]. This modest beneficial effect of dual therapy was counterbalanced by an increased risk of bleeding. Some groups suggest the use of dual antiplatelet therapy for at least 1 month after endovascular therapy for LEAD with a stent implantation irrespective of its type [90].

\section{Anticoagulant therapy}

Anticoagulation strategy is currently advisable in the presence of its traditional indication (e.g. atrial fibrillation), although new drugs have provided encouraging findings for LEAD-related events. The cardiovascular outcomes for people using anticoagulation strategies (COMPASS) trial showed that rivaroxaban, an oral factor Xa inhibitor, plus aspirin was associated with fewer adverse cardiovascular events, but more major bleeding events versus aspirin alone [113]. The rivaroxaban treatment was also associated with reduced major limb events 
in patients with carotid or lower-limb peripheral artery disease. This benefit was reliable in participants with or without diabetes at baseline [114]. The Trial to Assess the Effects of SCH 530348 in Preventing Heart Attack and Stroke in Patients With Atherosclerosis (TRA2 ${ }^{\circ} \mathrm{P}-$ TIMI 50) revealed that Vorapaxar, a novel antagonist of protease-activated receptor-1, reduced the rates of hospitalization for acute limb ischemia and peripheral artery revascularization, but did not reduce the risk of cardiovascular death, myocardial infarction, or stroke in patients with stable atherosclerotic vascular disease and LEAD [115]. The Vorapaxar use was also associated with an increased risk of bleeding. These new therapies may improve the management of patients with LEAD, but the excess risk of bleeding should be seriously considered.

\section{Multifactorial intervention therapy}

The Steno2 trial has compared a multifactorial intervention versus conventional treatment in patients with type 2 diabetes and microalbuminuria [116]. During the 7.8-year in-trial period, Gæde and co-workers observed a fewer number of LLA (7 versus 14) and surgical procedures for peripheral atherosclerotic artery disease (6 versus 12) in participants assigned to multifactorial versus conventional therapy. These benefits persisted during the 5.5-year observational post-trial period [117]. On the other hand, no difference was observed in term of lower limb vascular events (amputation or revascularisation) in the Japan Diabetes Optimal Treatment study for 3 major risk factors of cardiovascular diseases (J-DOIT3) that compared the effectiveness and safety of a multifactorial intervention for control of glucose, blood pressure, and LDL cholesterol, versus strategy based on the ongoing Japanese guidelines in patients with type 2 diabetes [118].

\section{Other vasodilator therapies}

Some vasodilator agents may be used to relieve intermittent claudication and increase walking distance in patients with LEAD. The cilostazol, a selective inhibitor of the phosphodiesterase III, is the most studied drug; its benefit is modest with no evidence for vascular protection. In a comprehensive meta-analyses, cilostazol improved walking distance with no relevant cardiovascular effect or improvement in quality of life [119]. This vasodilator is responsible for some adverse effects including headaches, vertigo, palpitations, and diarrhea. The cilostazol also acts as an antiplatelet drug and therefore must be associated cautiously with other antiplatelet drugs or anticoagulant agents [120]. Naftidrofuryl, a peripheral vasodilator, also improved significantly the walking distance [121]. Finally, Buflomedil, a vasoactive agent, has only a small benefit in term of IC, and has been linked to some safety concerns including lethal and non-lethal neurologic and cardiovascular events in cases of accidental and voluntary overdoses [122].

\section{Innovating treatment}

Growth factor therapy

Some data suggested a relationship between circulating levels of growth factors and the development of LEAD [123]. The therapies using growth factors, delivered directly (as recombinant proteins), or indirectly (e.g. by viral vectors or DNA plasmids encoding these factors), have been tested in LEAD with contrasting findings. The Efficacy and Safety of XRP0038/NV1FGF in Critical Limb Ischemia Patients With Skin Lesions (TA-MARIS) trial did not show relevance of non-viral 1 fibroblast growth factor in the reduction of death or LLA in 520 participants (53\% with diabetes) with critical limb ischemia unable for revascularisation [124]. A recent meta-analysis of 14 RCTs investigating fibroblast, hepatocyte, and vascular endothelial growth factors did not support their use in patients with LEAD in term of death, major amputation, or IC. However, these factors may improve haemodynamic measurements and decrease the risk of minor amputation [125].

\section{Stem cell therapy}

Some studies have tested stem cell therapy in patients with LEAD with encouraging results, although the lack of definitive evidences. A recent systematic review of the literature and a meta-analysis have shown that autologous cell therapy reduced the risk of LLA and rest pain, improved wound healing, and increased ABI and TcPO2 in patients with LEAD who were ineligible for surgical or percutaneous revascularization [126]. Interestingly, the benefit of cell therapy on LLA rate was higher in trials with a high prevalence of diabetes at baseline. Cell therapy was not associated with severe adverse events. All benefits were especially observed in non-randomized studies and cell therapy versus standard care RCTs. However, these associated benefits were not significant in placebo-controlled randomized trials, and disappeared in RCTs with a low risk of bias. Further high-quality placebo-controlled randomized trials are needed to confirm the safety and the efficiency of autologous cell therapy in patients with LEAD. Of note, a recent placebo-compared RCT (Patients With Intermittent Claudication Injected With ALDH Bright Cells (PACE)) did not support the use of cell therapy in patients with LEAD [127]. PACE trial has not shown improvement in peak walking time, collateral count, peak hyperaemic popliteal flow, and capillary perfusion in patients with LEAD treated by autologous bone marrow-derived aldehyde dehydrogenase bright cells. 


\section{Other innovating procedure}

Remote ischaemic conditioning (RIC), involving repeated applications of short periods of limb ischemia over days or weeks, may improve endothelial function, skin microcirculation, and regulates the inflammatory response. Some data suggested that repeat RIC may boost healing of ischaemic diabetic foot [128].

\section{Lifestyle management}

\section{Smoking cessation}

Tobacco smoking including second-hand smoke has been highlighted as one of the three leading risk factors for global disease burden worldwide [129]. It is an independent risk factor for LEAD [12, 13, 16], and has been shown as a significant predictor for worse outcomes including peripheral events and death in patients with LEAD undergoing infra-inguinal bypass [130]. Tobacco smoking may induce prothrombotic and atherogenic abnormalities, and increase the risk of acute myocardial infarction, sudden cardiac death, stroke, aortic aneurysm, and LEAD [131, 132]. Both passive and active smoking cessation is required in all patients with peripheral arterial disease including LEAD. Health authorities should adopt effective public health policies limiting tobacco use, especially in low- and middle-income countries.

\section{Exercise training}

The exercise training improved walking ability, and distances, as well as physical function, vitality and general health [133]. However, the exercise training did not increase ABI, or reduce the risk of LLA, cardiovascular events, or mortality. Some data showed significant improvement in maximal and pain-free walking distance in participants assigned to supervised exercise therapy, compared with non-supervised exercise therapy regimens [134]. No significant difference was observed in term of quality of life parameters between the two exercise programs.

\section{Nutrition therapy}

Healthy diet might help to achieve and maintain body weight goals, reach individualized glycaemic, blood pressure, and lipid targets, and delay or prevent diabetic complications, especially microvascular disease [135]. Previous studies suggested the influence of nutrient quality on the prevalence of LEAD [136, 137]. A systematic review suggested that Omega- 3 fatty acids might have modest haematological benefit in people with IC, but no improvement in walking distance, $\mathrm{ABI}$, angiographic measurements, or quality of life [138]. Interestingly, a Spanish trial has suggested that the Mediterranean diet supplemented with extra-virgin olive oil or nuts, compared with a low-fat diet, was associated with a lower risk of LEAD [139].

\section{Surgical or endovascular revascularization}

Contrasting observations were reported in terms of perioperative outcomes in patients with diabetes undergoing revascularization [140-144]. Recent studies have shown similar peri- and post-operative mortality in patients with diabetes, compared with those without diabetes, but diabetic patients had a higher risk of incomplete wound healing and major amputation, a prolonged length of hospital stay and more frequent readmission [143, 144]. Surgical revascularization provides good long-term patency, although with a longer hospital stay and increased risk for perioperative complications and mortality, when compared with endovascular procedure [145]. The development of new techniques last decades has encouraged the implementation of endovascular therapy in patients with LEAD. The different options of revascularization depend on several factors including anatomical location, extension, and length of arterial lesions; general health condition of each patient and comorbidities; as well as centre and surgeon experience. The endovascular revascularization may be a good strategy for short $(<5 \mathrm{~cm})$ stenosis or occlusion of iliac arteries, providing a good long-term patency [146]. Whereas, a hybrid procedure (endarterectomy or bypass at the femoral level combined with endovascular therapy) may be indicated for ilio-femoral lesions [147]. Aorto-femoral bypass is the first line strategy in aorto-iliac occlusions in patients who fit for surgery [148], while an endovascular procedure should be considered in long or bilateral lesions in patients with severe comorbidities [145, 149]. An endovascular revascularization may be also considered as a first strategy for aorto-iliac occlusive lesions if done by an experienced team without compromising subsequent surgical options [150]. In femoro-popliteal stenosis/ occlusions $<25 \mathrm{~cm}$, an endovascular revascularization may be considered as the first-line therapy, and a primary stent implantation has been associated with further morphological benefits $[151,152]$. If the occlusion/stenosis is more than $25 \mathrm{~cm}$, surgical bypass may be an appropriate option with a better long-term patency, especially when using the great saphenous vein. The infra-popliteal artery disease is a common LEAD presentation in patients with diabetes. The ESC and ESVS recommends endovascular therapy as first choice in infra-popliteal artery disease with stenotic lesions and short occlusions, while bypass with an autologous vein gives may be discussed for long occlusions (Table 1) [90]. However, endovascular therapy can be tried in patients with long occlusions if the surgical risk is judged as high, or in the absence of autologous 
vein. The angiosome concept, targeting the ischaemic tissues, may also be considered.

\section{Conclusion}

LEAD is one of the most severe conditions seen in patients with diabetes. It leads to excess risk of death, CVD, and limb loss, and is responsible for disabilities and an important socio-economical burden. The diagnosis strategy has been better codified now focusing in patients with evocative symptoms of LEAD, far from the worthless and expensive universal screening in asymptomatic patients. Anti-diabetic, anti-hypertensive, lipid-lowering and antiplatelet medications may improve the cardiovascular prognosis of patients with LEAD, but few has been done to test their benefits to reduce the occurrence and the progression of LEAD as well as lower-extremities adverse events. High quality studies are required to advance the knowledge in pathophysiology and natural history of LEAD, and to evaluate different aspects of its management.

\section{Abbreviations}

ABI: Ankle-Brachial Index; ACC: American College of Cardiology; ACCORD: Action to Control Cardiovascular Risk in Diabetes; ADA: American Diabetes Association; ADVANCE: Action in Diabetes and Vascular Disease: PreterAx and DiamicroN Modified-Release Controlled Evaluation; AHA: American Heart Association; BARI-2D: Bypass Angioplasty Revascularization Investigation 2 Diabetes; CANVAS: Canagliflozine Cardiovascular Assessment Study; CAPRIE: Clopidogrel versus Aspirin in Patients at Risk of Ischaemic Events; CHARISMA: Clopidogrel for High Atherothrombotic Risk and Ischemic Stabilization Management, and Avoidance; CKD: Chronic Kidney Disease; CLI: Critical Limb Ischemia; COMPASS: Cardiovascular outcomes for people using anticoagulation strategies; CVD: CardioVascular Disease; DPP-4: DiPeptidyl Peptidase 4; EMPA-REG OUTCOME: Empagliflozin cardiovascular outcome event trial in type 2 diabetes mellitus patients_-removing excess glucose; ESC: European Society of Cardiology; ESVS: European Society of Vascular Surgery; EXCEL: Exenatide Study of Cardiovascular Event Lowering; FDA: Food and Drug Administration; FIELD: Fenofibrate Intervention and Event Lowering in Diabetes; FOURIER: Further cardiovascular outcomes research with PCSK9 Inhibition in subjects with elevated risk; GLP-1: Glucagon-Like Peptide-1; IC: Intermittent Claudication; J-DOIT3: Japan Diabetes Optimal Treatment study for 3 major risk factors of cardiovascular diseases; LEAD: Lower Extremity Arterial Disease; LEADER: Liraglutide effect and action in diabetes: evaluation of cardiovascular outcome results; LLA: Lower Limb Amputation; PACE: Patients with intermittent claudication injected with ALDH bright cells; PCSK9: Proprotein Convertase Subtilisin/Kexin type 9; POPADAD: Progression of arterial disease and diabetes trial; PPAR: Peroxisome proliferator-activated receptor; PROactive: pROspective pioglitAzone Clinical Trial In macroVascular Events; RCT: Randomized Clinical Trial; REACH: Reduction of atherothrombosis for continued health registry; RIC: Remote Ischaemic Conditioning; SGLT2: Sodium GLucose co-Transporter 2; SVS: Society of Vascular Surgery; TA-MARIS: Efficacy and Safety of XRP0038/NV1FGF in Critical Limb Ischemia Patients with Skin Lesions; TNRF1:Tumor Necrosis Factor-a Receptor 1; TRA2 ${ }^{\circ} \mathrm{P}$-TIMI 50: Trial to Assess the Effects of SCH 530348 in Preventing Heart Attack and Stroke in Patients With Atherosclerosis; UKPDS: UK Prospective Diabetes Study; USPSTF: US Preventive Services Task Force; VADT:Veterans Affairs DiabeTes; WIFI: Wound Ischemia and Foot Infection.

\section{Authors' contributions}

MN and KM reviewed literature, researched data, and drafted the manuscript; $L P, L A, L B B, E D, G V, M M, R R$, and VR contributed to the discussion and reviewed the manuscript. KM is the guarantor of this work. All authors read and approved the final manuscript.

\section{Author details}

1 Département d'Endocrinologie, Diabétologie, Nutrition, Hôpital HautLévêque, Avenue de Magellan, 33604 Pessac Cedex, France. ${ }^{2}$ Département d'Endocrinologie, Diabétologie, Nutrition, Assistance Publique - Hôpitaux de Paris, Hospital Bichat, DHU FIRE, Paris, France. ${ }^{3}$ UFR de Médecine, Université Paris Diderot, Sorbonne Paris Cité, Paris, France. ${ }^{4}$ INSERM, UMRS 1138, Centre de Recherche des Cordeliers, Paris, France. ${ }^{5}$ Faculté de Médecine, Université de Bordeaux, Bordeaux, France. ${ }^{6}$ Département de Chirurgie Vasculaire, CHU de Bordeaux, Bordeaux, France. ${ }^{7}$ Fondation Adolphe de Rothschild Hospital, Paris, France.

\section{Acknowledgements}

Not applicable.

Competing interests

The authors declare that they have no competing interests.

\section{Availability of data and materials}

Not applicable.

Consent for publication

Not applicable.

Ethics approval and consent to participate

Not applicable.

Funding

Not applicable.

\section{Publisher's Note}

Springer Nature remains neutral with regard to jurisdictional claims in published maps and institutional affiliations.

Received: 18 August 2018 Accepted: 17 October 2018

Published online: 23 October 2018

\section{References}

1. Jude EB, Oyibo SO, Chalmers N, Boulton AJ. Peripheral arterial disease in diabetic and nondiabetic patients: a comparison of severity and outcome. Diabetes Care. 2001;24(81):1433-7.

2. Norman PE, Davis WA, Bruce DG, Davis TM. Peripheral arterial disease and risk of cardiac death in type 2 diabetes: the Fremantle Diabetes Study. Diabetes Care. 2006;29(31):575-80.

3. Criqui MH, Aboyans V. Epidemiology of peripheral artery disease. Circ Res. 2015;116(9l):1509-26.

4. Selvin E, Erlinger TP. Prevalence of and risk factors for peripheral arterial disease in the United States: results from the National Health and Nutrition Examination Survey, 1999-2000. Circulation. 2004;1 10(61):738-43.

5. Fowkes FG, Rudan D, Rudan I, Aboyans V, Denenberg JO, McDermott MM, Norman PE, Sampson UK, Williams LJ, Mensah GA, et al. Comparison of global estimates of prevalence and risk factors for peripheral artery disease in 2000 and 2010: a systematic review and analysis. Lancet. 2013;382(99011):1329-40.

6. Sampson UK, Fowkes FG, McDermott MM, Criqui MH, Aboyans V, Norman PE, Forouzanfar MH, Naghavi M, Song Y, Harrell FE Jr, et al. Global and regional burden of death and disability from peripheral artery disease: 21 world regions, 1990 to 2010. Glob Heart. 2014;9(11):145-158.e121.

7. Mueller T, Hinterreiter F, Luft C, Poelz W, Haltmayer M, Dieplinger B. Mortality rates and mortality predictors in patients with symptomatic peripheral artery disease stratified according to age and diabetes. JVasc Surg. 2014;59(51):1291-9.

8. Li MF, Zhao CC, LiTT, Tu YF, Lu JX, Zhang R, Chen MY, Bao YQ, Li LX, Jia WP. The coexistence of carotid and lower extremity atherosclerosis further increases cardio-cerebrovascular risk in type 2 diabetes. Cardiovasc Diabetol. 2016;15:43.

9. Boyko EJ, Seelig AD, Ahroni JH. Limb- and person-level risk factors for lower-limb amputation in the prospective seattle diabetic foot study. Diabetes Care. 2018;41(41):891-8. 
10. Mohammedi K, Woodward M, Hirakawa Y, Zoungas S, Colagiuri S, Hamet P, Harrap S, Poulter N, Matthews DR, Marre M, et al. Presentations of major peripheral arterial disease and risk of major outcomes in patients with type 2 diabetes: results from the ADVANCE-ON study. Cardiovasc Diabetol. 2016;15(11):129.

11. Dormandy JA, Betteridge DJ, Schernthaner G, Pirags V, Norgren L. Impact of peripheral arterial disease in patients with diabetes-results from PROactive (PROactive 11). Atherosclerosis. 2009;202(11):272-81.

12. Adler Al, Stevens RJ, Neil A, Stratton IM, Boulton AJ, Holman RR. UKPDS 59: hyperglycemia and other potentially modifiable risk factors for peripheral vascular disease in type 2 diabetes. Diabetes Care 2002;25(51):894-9.

13. Mohammedi $K$, Woodward M, Hirakawa Y, Zoungas S, Williams B, Lisheng L, Rodgers A, Mancia G, Neal B, Harrap S, et al. Microvascular and macrovascular disease and risk for major peripheral arterial disease in patients with type 2 diabetes. Diabetes Care. 2016;39(10l):1796-803.

14. Prompers L, Huijberts M, Apelqvist J, Jude E, Piaggesi A, Bakker K, Edmonds M, Holstein P, Jirkovska A, Mauricio D, et al. High prevalence of ischaemia, infection and serious comorbidity in patients with diabetic foot disease in Europe. Baseline results from the Eurodiale study. Diabetologia. 2007;50(11):18-25.

15. Mohammedi K, Woodward M, Zoungas S, Li Q, Harrap S, Patel A, Marre M, Chalmers J. Absence of peripheral pulses and risk of major vascular outcomes in patients with type 2 diabetes. Diabetes Care. 2016;39(12l):2270-7.

16. Althouse AD, Abbott JD, Forker AD, Bertolet M, Barinas-Mitchell $E_{\text {, }}$ Thurston RC, Mulukutla S, Aboyans V, Brooks MM. Risk factors for incident peripheral arterial disease in type 2 diabetes: results from the Bypass Angioplasty Revascularization Investigation in type 2 Diabetes (BARI 2D) Trial. Diabetes Care. 2014;37(5I):1346-52.

17. Han E, Lee YH, Lee BW, Kang ES, Lee IK, Cha BS. Anatomic fat depots and cardiovascular risk: a focus on the leg fat using nationwide surveys (KNHANES 2008-2011). Cardiovasc Diabetol. 2017;16(11):54.

18. Matsushita K, Ballew SH, Coresh J, Arima H, Arnlov J, Cirillo M, Ebert N, Hiramoto JS, Kimm H, Shlipak MG, et al. Measures of chronic kidney disease and risk of incident peripheral artery disease: a collaborative meta-analysis of individual participant data. Lancet Diabetes Endocrinol. 2017:5(91):718-28.

19. Sebastianski M, Makowsky MJ, Dorgan M, Tsuyuki RT. Paradoxically lower prevalence of peripheral arterial disease in South Asians: a systematic review and meta-analysis. Heart. 2014;100(2l):100-5.

20. Bauer TA, Brass EP, Hiatt WR. Impaired muscle oxygen use at onset of exercise in peripheral arterial disease. J Vasc Surg. 2004;40(31):488-93.

21. Edwards AT, Blann AD, Suarez-Mendez VJ, Lardi AM, McCollum CN. Systemic responses in patients with intermittent claudication after treadmill exercise. Br J Surg. 1994:81(121):1738-41.

22. Belch JJ, Mackay IR, Hill A, Jennings P, McCollum P. Oxidative stress is present in atherosclerotic peripheral arterial disease and further increased by diabetes mellitus. Int Angiol. 1995;14(41):385-8.

23. Malmstedt J, Karvestedt L, Swedenborg J, Brismar K. The receptor for advanced glycation end products and risk of peripheral arterial disease, amputation or death in type 2 diabetes: a population-based cohort study. Cardiovasc Diabetol. 2015;14:93.

24. Mangiafico RA, Malatino LS, Spada RS, Santonocito M, Messina R, Dell'Arte S, Attina T. Treadmill exercise-induced release of endothelin-1 in patients with peripheral arterial occlusive disease at Fontaine stage Ilb. Int Angiol. 2000;19(1):14-7.

25. Nativel M, Schneider F, Saulnier PJ, Gand E, Ragot S, Meilhac O, Rondeau $P$, Burillo $E$, Cournot $M$, Potier $L$, et al. Prognostic values of inflammatory and redox status biomarkers on the risk of major lower-extremity artery disease in individuals with type 2 diabetes. Diabetes Care. 2018:41:2162-9.

26. Brevetti G, Schiano V, Chiariello M. Endothelial dysfunction: a key to the pathophysiology and natural history of peripheral arterial disease? Atherosclerosis. 2008;197(1):1-11.

27. Taniwaki H, Shoji T, Emoto M, Kawagishi T, Ishimura E, Inaba M, Okuno Y, Nishizawa Y. Femoral artery wall thickness and stiffness in evaluation of peripheral vascular disease in type 2 diabetes mellitus. Atherosclerosis. 2001;158(11):207-14

28. Suzuki E, Kashiwagi A, Nishio Y, Egawa K, Shimizu S, Maegawa $H_{\text {, }}$ Haneda M, Yasuda H, Morikawa S, Inubushi T, et al. Increased arterial wall stiffness limits flow volume in the lower extremities in type 2 diabetic patients. Diabetes Care. 2001;24(121):2107-14.

29. Emdin CA, Anderson SG, Callender T, Conrad N, Salimi-Khorshidi G, Mohseni H, Woodward M, Rahimi K. Usual blood pressure, peripheral arterial disease, and vascular risk: cohort study of 4.2 million adults. BMJ. 2015;351:h4865.

30. Mohammedi K, Potier L, Belhatem N, Matallah N, Hadjadj S, Roussel R, Marre M, Velho G. Lower-extremity amputation as a marker for renal and cardiovascular events and mortality in patients with long standing type 1 diabetes. Cardiovasc Diabetol. 2016;15:5.

31. Mohammedi K, Woodward M, Marre M, Colagiuri S, Cooper M, Harrap S, Mancia G, Poulter N, Williams B, Zoungas S, et al. Comparative effects of microvascular and macrovascular disease on the risk of major outcomes in patients with type 2 diabetes. Cardiovasc Diabetol. 2017;16(11):95.

32. Fiordaliso F, Clerici G, Maggioni S, Caminiti M, Bisighini C, Novelli D, Minnella D, Corbelli A, Morisi R, De laco A, et al. Prospective study on microangiopathy in type 2 diabetic foot ulcer. Diabetologia. 2016;59(7l):1542-8.

33. Luders F, Bunzemeier H, Engelbertz C, Malyar NM, Meyborg M, Roeder $\mathrm{N}$, Berger K, Reinecke H. CKD and acute and long-term outcome of patients with peripheral artery disease and critical limb ischemia. Clin J Am Soc Nephrol. 2016;11(2l):216-22.

34. American Diabetes Association. Microvascular complications and foot care: standards of medical care in diabetes_-2018. Diabetes Care. 2018;41 (Supplement 1):S105-18.

35. Jeffcoate WJ, Rasmussen LM, Hofbauer LC, Game FL. Medial arterial calcification in diabetes and its relationship to neuropathy. Diabetologia. 2009;52(12l):2478-88.

36. Lehto S, Niskanen L, Suhonen M, Ronnemaa T, Laakso M. Medial artery calcification. A neglected harbinger of cardiovascular complications in non-insulin-dependent diabetes mellitus. Arterioscler Thromb Vasc Biol. 1996;16(81):978-83.

37. Rutherford RB, Baker JD, Ernst C, Johnston KW, Porter JM, Ahn S, Jones DN. Recommended standards for reports dealing with lower extremity ischemia: revised version. J Vasc Surg. 1997;26(31):517-38.

38. Lundin M, Wiksten JP, Perakyla T, Lindfors O, Savolainen H, Skytta J, Lepantalo M. Distal pulse palpation: is it reliable? World J Surg. 1999;23(31):252-5.

39. Mowlavi A, Whiteman J, Wilhelmi BJ, Neumeister MW, MCLafferty R. Dorsalis pedis arterial pulse: palpation using a bony landmark. Postgrad Med J. 2002;78(9261):746-7.

40. Criqui MH, Fronek A, Klauber MR, Barrett-Connor E, Gabriel S. The sensitivity, specificity, and predictive value of traditional clinical evaluation of peripheral arterial disease: results from noninvasive testing in a defined population. Circulation. 1985;71(31):516-22.

41. Hiatt WR, Marshall JA, Baxter J, Sandoval R, Hildebrandt W, Kahn LR, Hamman RF. Diagnostic methods for peripheral arterial disease in the San Luis Valley Diabetes Study. J Clin Epidemiol. 1990;43(6I):597-606.

42. Collins TC, Suarez-Almazor M, Peterson NJ. An absent pulse is not sensitive for the early detection of peripheral arterial disease. Fam Med. 2006:38(11):38-42.

43. Armstrong DW, Tobin C, Matangi MF. The accuracy of the physical examination for the detection of lower extremity peripheral arterial disease. Can J Cardiol. 2010;26(101):e346-50.

44. Weiss NS, McClelland R, Criqui MH, Wassel CL, Kronmal R. Incidence and predictors of clinical peripheral artery disease in asymptomatic persons with a low ankle-brachial index. J Med Screen. 2018. https:// doi.org/10.1177/0969141318773782.

45. Potier L, Roussel R, Labreuche J, Marre M, Cacoub P, Rother J, Wilson PW, Goto S, Bhatt DL, Steg PG. Interaction between diabetes and a high ankle-brachial index on mortality risk. Eur J Prev Cardiol. 2015;22(51):615-21.

46. Curry SJ, Krist AH, Owens DK, Barry MJ, Caughey AB, Davidson KW, Doubeni CA, Epling JW Jr, Kemper AR, Kubik M, et al. Screening for peripheral artery disease and cardiovascular disease risk assessment with the ankle-brachial index: US preventive services task force recommendation statement. JAMA. 2018;320(21):177-83.

47. Guirguis-Blake JM, Evans CV, Redmond N, Lin JS. Screening for peripheral artery disease using the ankle-brachial index: updated evidence report and systematic review for the US preventive services task force. JAMA. 2018;320(2l):184-96. 
48. Potier L, Abi Khalil C, Mohammedi K, Roussel R. Use and utility of ankle brachial index in patients with diabetes. Eur J Vasc Endovasc Surg. 2011;41(11):110-6.

49. Davies JH, Kenkre J, Williams EM. Current utility of the ankle-brachial index $(A B I)$ in general practice: implications for its use in cardiovascular disease screening. BMC Fam Pract. 2014;15:69.

50. Polak JF. Peripheral arterial disease. Evaluation with color flow and duplex sonography. Radiol Clin North Am. 1995;33(1I):71-90.

51. Brownrigg JR, Hinchliffe RJ, Apelqvist J, Boyko EJ, Fitridge R, Mills JL, Reekers J, Shearman CP, Zierler RE, Schaper NC. Effectiveness of bedside investigations to diagnose peripheral artery disease among people with diabetes mellitus: a systematic review. Diabetes Metab Res Rev. 2016;32(Suppl):1119-27.

52. Santoro L, Ferraro PM, Flex A, Nesci A, De Matteis G, Di Giorgio A, Zaccone V, Gambaro G, Gasbarrini A, Santoliquido A. New semiquantitative ultrasonographic score for peripheral arterial disease assessment and its association with cardiovascular risk factors. Hypertens Res. 2016;39(12I):868-73

53. Santoro L, Flex A, Nesci A, Ferraro PM, De Matteis G, Di Giorgio A, Giupponi B, Saviano L, Gambaro G, Franceschi F, et al. Association between peripheral arterial disease and cardiovascular risk factors: role of ultrasonography versus ankle-brachial index. Eur Rev Med Pharmacol Sci. 2018;22(10l):3160-5

54. Aboyans V, Desormais I, Lacroix P, Salazar J, Criqui MH, Laskar M. The general prognosis of patients with peripheral arterial disease differs according to the disease localization. J Am Coll Cardiol. 2010:55(91):898-903.

55. Teraa M, Conte MS, Moll FL, Verhaar MC. Critical limb ischemia. Current trends and future directions. J Am Heart Assoc. 2016;5(2l):e002938.

56. Mills JL Sr, Conte MS, Armstrong DG, Pomposelli FB, Schanzer A, Sidawy AN, Andros $G$. The society for vascular surgery lower extremity threatened limb classification system: risk stratification based on wound, ischemia, and foot infection (WIfI). J Vasc Surg. 2014;59(1I):220-234. e221-222.

57. Gonzalez-Clemente JM, Pinies JA, Calle-Pascual A, Saavedra A, Sanchez C, Bellido D, Martin-Folgueras T, Moraga I, Recasens A, Girbes J, et al. Cardiovascular risk factor management is poorer in diabetic patients with undiagnosed peripheral arterial disease than in those with known coronary heart disease or cerebrovascular disease. Results of a nationwide study in tertiary diabetes centres. Diabet Med. 2008;25(4I):427-34

58. Berger JS, Ladapo JA. Underuse of prevention and lifestyle counseling in patients with peripheral artery disease. J Am Coll Cardiol. 2017;69(18I):2293-300.

59. Diabetes Control and Complications Trial Research Group. The effect of intensive treatment of diabetes on the development and progression of long-term complications in insulin-dependent diabetes mellitus. N Engl J Med. 1993;329(141):977-86.

60. UKPDS Group. Intensive blood-glucose control with sulphonylureas or insulin compared with conventional treatment and risk of complications in patients with type 2 diabetes (UKPDS 33). Lancet. 1998:352(91311):837-53.

61. Patel A, MacMahon S, Chalmers J, Neal B, Billot L, Woodward M, Marre M, Cooper M, Glasziou P, Grobbee D, et al. Intensive blood glucose control and vascular outcomes in patients with type 2 diabetes. N Engl J Med. 2008;358(24l):2560-72.

62. Stratton IM, Adler Al, Neil HA, Matthews DR, Manley SE, Cull CA, Hadden D, Turner RC, Holman RR. Association of glycaemia with macrovascular and microvascular complications of type 2 diabetes (UKPDS 35): prospective observational study. BMJ. 2000;321(7258I):405-12.

63. Holman RR, Paul SK, Bethel MA, Matthews DR, Neil HA. 10-year followup of intensive glucose control in type 2 diabetes. N Engl J Med. 2008;359(15I):1577-89.

64. Hasan R, Firwana B, Elraiyah T, Domecq JP, Prutsky G, Nabhan M, Prokop $L$, Henke P, Tsapas A, Montori VM, et al. A systematic review and meta-analysis of glycemic control for the prevention of diabetic foot syndrome. J Vasc Surg. 2016;63(2 Suppll):22S-28S.e21-22.

65. Dormandy JA, Charbonnel B, Eckland DJ, Erdmann E, Massi-Benedetti M, Moules IK, Skene AM, Tan MH, Lefebvre PJ, Murray GD, et al. Secondary prevention of macrovascular events in patients with type 2 diabetes in the PROactive Study (PROspective pioglitAzone Clinical
Trial In macroVascular Events): a randomised controlled trial. Lancet. 2005;366(9493I):1279-89.

66. Althouse AD, Abbott JD, Sutton-Tyrrell K, Forker AD, Lombardero MS, Buitron LV, Pena-Sing I, Tardif JC, Brooks MM, et al. Favorable effects of insulin sensitizers pertinent to peripheral arterial disease in type 2 diabetes: results from the Bypass Angioplasty Revascularization Investigation 2 Diabetes (BARI 2D) trial. Diabetes Care. 2013;36(10I):3269-75.

67. Mary A, Hartemann A, Liabeuf S, Aubert CE, Kemel S, Salem JE, Cluzel $P$, Lenglet A, Massy ZA, Lalau JD, et al. Association between metformin use and below-the-knee arterial calcification score in type 2 diabetic patients. Cardiovasc Diabetol. 2017;16(11):24

68. Scirica BM, Bhatt DL, Braunwald E, Steg PG, Davidson J, Hirshberg B, Ohman P, Frederich R, Wiviott SD, Hoffman EB, et al. Saxagliptin and cardiovascular outcomes in patients with type 2 diabetes mellitus. $\mathrm{N}$ Engl J Med. 2013;369(14I):1317-26.

69. White WB, Cannon CP, Heller SR, Nissen SE, Bergenstal RM, Bakris GL, Perez AT, Fleck PR, Mehta CR, Kupfer S, et al. Alogliptin after acute coronary syndrome in patients with type 2 diabetes. N Engl J Med. 2013;369(14I):1327-35.

70. Green JB, Bethel MA, Armstrong PW, Buse JB, Engel SS, Garg J, Josse R, Kaufman KD, Koglin J, Korn S, et al. Effect of sitagliptin on cardiovascular outcomes in type 2 diabetes. N Engl J Med. 2015;373(3I):232-42.

71. Pfeffer MA, Claggett B, Diaz R, Dickstein K, Gerstein HC, Kober LV, Lawson FC, Ping L, Wei $X$, Lewis EF, et al. Lixisenatide in patients with type 2 diabetes and acute coronary syndrome. N Engl J Med. 2015;373(23I):2247-57.

72. Zinman B, Wanner C, Lachin JM, Fitchett D, Bluhmki E, Hantel S, Mattheus M, Devins T, Johansen OE, Woerle HJ, et al. Empagliflozin, cardiovascular outcomes, and mortality in type 2 diabetes. $\mathrm{N}$ Engl J Med. 2015;373(221):2117-28.

73. Marso SP, Bain SC, Consoli A, Eliaschewitz FG, Jodar E, Leiter LA, Lingvay I, Rosenstock J, Seufert J, Warren ML, et al. Semaglutide and cardiovascular outcomes in patients with type 2 diabetes. N Engl J Med. 2016;375(19l):1834-44.

74. Marso SP, Daniels GH, Brown-Frandsen K, Kristensen P, Mann JF, Nauck MA, Nissen SE, Pocock S, Poulter NR, Ravn LS, et al. Liraglutide and cardiovascular outcomes in type 2 diabetes. N Engl J Med. 2016:375(41):311-22.

75. Neal B, Perkovic V, Mahaffey KW, de Zeeuw D, Fulcher G, Erondu N, Shaw W, Law G, Desai M, Matthews DR. Canagliflozin and cardiovascular and renal events in type 2 diabetes. N Engl J Med. 2017;377(7l):644-57.

76. Hernandez AF, Green JB, Janmohamed S, D'Agostino RB Sr, Granger $C B$, Jones NP, Leiter LA, Rosenberg AE, Sigmon KN, Somerville MC, et al. Albiglutide and cardiovascular outcomes in patients with type 2 diabetes and cardiovascular disease (Harmony Outcomes): a doubleblind, randomised placebo-controlled trial. Lancet. 2018. https://doi. org/10.1016/S0140-6736(18)32261-X.

77. Dhatariya K, Bain SC, Buse JB, Simpson R, Tarnow L, Kaltoft MS, Stellfeld M, Tornoe K, Pratley RE. The impact of liraglutide on diabetes-related foot ulceration and associated complications in patients with type 2 diabetes at high risk for cardiovascular events: results from the LEADER trial. Diabetes Care. 2018;41:2229-35.

78. Holman RR, Bethel MA, Mentz RJ, Thompson VP, Lokhnygina Y, Buse JB, Chan JC, Choi J, Gustavson SM, lqbal N, et al. Effects of once-weekly exenatide on cardiovascular outcomes in type 2 diabetes. N Engl J Med. 2017;377(13I):1228-39.

79. Udell JA, Yuan Z, Rush T, Sicignano NM, Galitz M, Rosenthal N. Cardiovascular outcomes and risks after initiation of a sodium glucose cotransporter 2 inhibitor: results from the EASEL population-based cohort study (evidence for cardiovascular outcomes with sodium glucose cotransporter 2 inhibitors in the real world). Circulation. 2018;137(14l):1450-9.

80. Khouri C, Cracowski JL, Roustit M. SGLT-2 inhibitors and the risk of lower-limb amputation: is this a class effect? Diabetes Obes Metab. 2018;20(6I):1531-4.

81. Chang HY, Singh S, Mansour O, Baksh S, Alexander GC. Association between sodium-glucose cotransporter 2 inhibitors and lower extremity amputation among patients with type 2 diabetes. JAMA Intern Med. 2018:178:1190-8 
82. Inzucchi SE, lliev H, Pfarr E, Zinman B. Empagliflozin and assessment of lower-limb amputations in the EMPA-REG OUTCOME trial. Diabetes Care. 2018;41(11):e4-5.

83. Yuan Z, DeFalco FJ, Ryan PB, Schuemie MJ, Stang PE, Berlin JA, Desai M, Rosenthal N. Risk of lower extremity amputations in people with type 2 diabetes mellitus treated with sodium-glucose co-transporter-2 inhibitors in the USA: a retrospective cohort study. Diabetes Obes Metab. 2018;20(3I):582-9.

84. Gerhard-Herman MD, Gornik HL, Barrett C, Barshes NR, Corriere MA, Drachman DE, Fleisher LA, Fowkes FG, Hamburg NM, Kinlay S, et al. 2016 AHA/ACC guideline on the management of patients with lower extremity peripheral artery disease: a report of the American College of Cardiology/American Heart Association task force on clinical practice guidelines. Circulation. 2017;135(121):e726-79.

85. Lane DA, Lip GY. Treatment of hypertension in peripheral arterial disease. Cochrane Database Syst Rev. 2013. https://doi.org/10.1002/14651 858.CD003075.pub2.

86. Itoga NK, Tawfik DS, Lee CK, Maruyama S, Leeper NJ, Chang TI. Association of blood pressure measurements with peripheral arterial disease events: a reanalysis of the ALLHAT Data. Circulation. 2018. https://doi. org/10.1161/CIRCULATIONAHA.118.033348.

87. Dart AM, Kingwell BA. Pulse pressure-a review of mechanisms and clinical relevance. J Am Coll Cardiol. 2001;37(41):975-84.

88. Adler Al, Stratton IM, Neil HA, Yudkin JS, Matthews DR, Cull CA, Wright AD, Turner RC, Holman RR. Association of systolic blood pressure with macrovascular and microvascular complications of type 2 diabetes (UKPDS 36): prospective observational study. BMJ. 2000;321(72581):412-9.

89. Anderson RJ, Bahn GD, Moritz TE, Kaufman D, Abraira C, Duckworth W, et al. Blood pressure and cardiovascular disease risk in the Veterans Affairs Diabetes Trial. Diabetes Care. 2011:34(11):34-8.

90. Aboyans V, Ricco JB, Bartelink MEL, Bjorck M, Brodmann M, Cohnert T, Collet JP, Czerny M, De Carlo M, Debus S, et al. 2017 ESC guidelines on the diagnosis and treatment of peripheral arterial diseases, in collaboration with the European Society for Vascular Surgery (ESVS): document covering atherosclerotic disease of extracranial carotid and vertebral, mesenteric, renal, upper and lower extremity arteries. Endorsed by: the European Stroke Organization (ESO) The Task Force for the Diagnosis and Treatment of Peripheral Arterial Diseases of the European Society of Cardiology (ESC) and of the European Society for Vascular Surgery (ESVS). Eur Heart J. 2018;39(9l):763-816.

91. Antoniou GA, Fisher RK, Georgiadis GS, Antoniou SA, Torella F. Statin therapy in lower limb peripheral arterial disease: systematic review and meta-analysis. Vasc Pharmacol. 2014;63(21):79-87.

92. Heart Protection Study Collaborative Group. Randomized trial of the effects of cholesterol-lowering with simvastatin on peripheral vascular and other major vascular outcomes in 20,536 people with peripheral arterial disease and other high-risk conditions. J Vasc Surg. 2007:45(4):645-54.

93. Westin GG, Armstrong EJ, Bang H, Yeo KK, Anderson D, Dawson DL, Pevec WC, Amsterdam EA, Laird JR. Association between statin medications and mortality, major adverse cardiovascular event, and amputation-free survival in patients with critical limb ischemia. J Am Coll Cardiol. 2014;63(7l):682-90.

94. Kumbhani DJ, Steg PG, Cannon CP, Eagle KA, Smith SC Jr, Goto S, Ohman EM, Elbez Y, Sritara P, Baumgartner I, et al. Statin therapy and long-term adverse limb outcomes in patients with peripheral artery disease: insights from the REACH registry. Eur Heart J. 2014;35(41I):2864-72.

95. Aung PP, Maxwell HG, Jepson RG, Price JF, Leng GC. Lipid-lowering for peripheral arterial disease of the lower limb. Cochrane Database Syst Rev. 2007. https://doi.org/10.1002/14651858.CD000123.pub2.

96. McDermott MM, Guralnik JM, Greenland P, Pearce WH, Criqui MH, Liu K, Taylor L, Chan C, Sharma L, Schneider JR, et al. Statin use and leg functioning in patients with and without lower-extremity peripheral arterial disease. Circulation. 2003;107(5I):757-61.

97. Momsen AH, Jensen MB, Norager CB, Madsen MR, VestersgaardAndersen T, Lindholt JS. Drug therapy for improving walking distance in intermittent claudication: a systematic review and meta-analysis of robust randomised controlled studies. Eur J Vasc Endovasc Surg. 2009:38(41):463-74.
98. Hsu CY, Chen YT, Su YW, Chang CC, Huang PH, Lin SJ. Statin therapy reduces future risk of lower-limb amputation in patients with diabetes and peripheral artery disease. J Clin Endocrinol Metab. 2017;102(7l):2373-81.

99. ACCORD study group. Effects of combination lipid therapy in type 2 diabetes mellitus. N Engl J Med. 2010;362:1563-74.

100. Keech A, Simes RJ, Barter P, Best J, Scott R, Taskinen MR, Forder P, Pillai A, Davis T, Glasziou P, et al. Effects of long-term fenofibrate therapy on cardiovascular events in 9795 people with type 2 diabetes mellitus (the FIELD study): randomised controlled trial. Lancet. 2005;366(9500l):1849-61.

101. Rajamani K, Colman PG, Li LP, Best JD, Voysey M, D’Emden MC, Laakso M, Baker JR, Keech AC. Effect of fenofibrate on amputation events in people with type 2 diabetes mellitus (FIELD study): a prespecified analysis of a randomised controlled trial. Lancet. 2009;373(9677l):1780-8.

102. Karatasakis A, Danek BA, Karacsonyi J, Rangan BV, Roesle MK, Knickelbine T, Miedema MD, Khalili H, Ahmad Z, Abdullah S, et al. Effect of PCSK9 inhibitors on clinical outcomes in patients with hypercholesterolemia: a meta-analysis of 35 randomized controlled trials. J Am Heart Assoc. 2017;6(12l):e006910.

103. Sabatine MS, Giugliano RP, Keech AC, Honarpour N, Wiviott SD, Murphy SA, Kuder JF, Wang H, Liu T, Wasserman SM, et al. Evolocumab and clinical outcomes in patients with cardiovascular disease. N Engl J Med. 2017;376(181):1713-22.

104. Sabatine MS, Leiter LA, Wiviott SD, Giugliano RP, Deedwania P, De Ferrari GM, Murphy SA, Kuder JF, Gouni-Berthold I, Lewis BS, et al. Cardiovascular safety and efficacy of the PCSK9 inhibitor evolocumab in patients with and without diabetes and the effect of evolocumab on glycaemia and risk of new-onset diabetes: a prespecified analysis of the FOURIER randomised controlled trial. Lancet Diabetes Endocrinol. 2017:5(121):941-50.

105. Bonaca MP, Nault P, Giugliano RP, Keech AC, Pineda AL, Kanevsky E, Kuder J, Murphy SA, Jukema JW, Lewis BS, et al. Low-density lipoprotein cholesterol lowering with evolocumab and outcomes in patients with peripheral artery disease: insights from the FOURIER Trial (further cardiovascular outcomes research with PCSK9 inhibition in subjects with elevated risk). Circulation. 2018;137(4l):338-50.

106. Fowkes FG, Price JF, Stewart MC, Butcher I, Leng GC, Pell AC, Sandercock PA, Fox KA, Lowe GD, Murray GD. Aspirin for prevention of cardiovascular events in a general population screened for a low ankle brachial index: a randomized controlled trial. JAMA. 2010;303(9l):841-8.

107. Belch J, MacCuish A, Campbell I, Cobbe S, Taylor R, Prescott R, Lee R, Bancroft J, MacEwan S, Shepherd J, et al. The prevention of progression of arterial disease and diabetes (POPADAD) trial: factorial randomised placebo controlled trial of aspirin and antioxidants in patients with diabetes and asymptomatic peripheral arterial disease. BMJ. 2008;337:a1840.

108. Antithrombotic Trialists' Collaboration. Collaborative meta-analysis of randomised trials of antiplatelet therapy for prevention of death, myocardial infarction, and stroke in high risk patients. BMJ. 2002;324(7329):71-86.

109. Berger JS, Krantz MJ, Kittelson JM, Hiatt WR. Aspirin for the prevention of cardiovascular events in patients with peripheral artery disease: a meta-analysis of randomized trials. JAMA. 2009;301(181):1909-19.

110. CAPRIE Steering Committee. A randomised, blinded, trial of clopidogrel versus aspirin in patients at risk of ischaemic events (CAPRIE). Lancet. 1996;348:1329-39.

111. Hiatt WR, Fowkes FG, Heizer G, Berger JS, Baumgartner I, Held P, Katona BG, Mahaffey KW, Norgren L, Jones WS, et al. Ticagrelor versus clopidogrel in symptomatic peripheral artery disease. N Engl J Med. 2017;376(1I):32-40.

112. Cacoub PP, Bhatt DL, Steg PG, Topol EJ, Creager MA. Patients with peripheral arterial disease in the CHARISMA trial. Eur Heart J. 2009;30(2I):192-201.

113. Eikelboom JW, Connolly SJ, Bosch J, Dagenais GR, Hart RG, Shestakovska O, Diaz R, Alings M, Lonn EM, Anand SS, et al. Rivaroxaban with or without aspirin in stable cardiovascular disease. N Engl J Med. 2017:377(141):1319-30.

114. Anand SS, Bosch J, Eikelboom JW, Connolly SJ, Diaz R, Widimsky P, Aboyans V, Alings M, Kakkar AK, Keltai K, et al. Rivaroxaban with or without aspirin in patients with stable peripheral or carotid artery disease: 
an international, randomised, double-blind, placebo-controlled trial. Lancet. 2017;391:219-29.

115. Bonaca MP, Scirica BM, Creager MA, Olin J, Bounameaux H, Dellborg M, Lamp JM, Murphy SA, Braunwald E, Morrow DA. Vorapaxar in patients with peripheral artery disease: results from TRA2 ${ }^{\circ} \mathrm{P}-\mathrm{TIMI} 50$. Circulation. 2013;127(14l):1522-1529, 1529e1521-1526.

116. Gaede P, Vedel P, Larsen N, Jensen GV, Parving HH, Pedersen O. Multifactorial intervention and cardiovascular disease in patients with type 2 diabetes. N Engl J Med. 2003;348(51):383-93.

117. Gaede P, Lund-Andersen $\mathrm{H}$, Parving HH, Pedersen O. Effect of a multifactorial intervention on mortality in type 2 diabetes. N Engl J Med. 2008;358(61):580-91.

118. Ueki K, Sasako T, Okazaki Y, Kato M, Okahata S, Katsuyama H, Haraguchi M, Morita A, Ohashi K, Hara K, et al. Effect of an intensified multifactorial intervention on cardiovascular outcomes and mortality in type 2 diabetes (J-DOIT3): an open-label, randomised controlled trial. Lancet Diabetes Endocrinol. 2017;5(121):951-64.

119. Bedenis R, Stewart M, Cleanthis M, Robless P, Mikhailidis DP, Stansby G. Cilostazol for intermittent claudication. Cochrane Database Syst Rev 2014. https://doi.org/10.1002/14651858.CD003748.pub4.

120. Hiatt WR, Money SR, Brass EP. Long-term safety of cilostazol in patients with peripheral artery disease: the CASTLE study (cilostazol: a study in long-term effects). J Vasc Surg. 2008;47(21):330-6.

121. De Backer TL, Vander Stichele R, Lehert P, Van Bortel L. Naftidrofuryl for intermittent claudication. Cochrane Database Syst Rev. 2008. https:// doi.org/10.1002/14651858.CD001368.pub3.

122. de Backer TL, Bogaert M, Vander Stichele R. Buflomedil for intermittent claudication. Cochrane Database Syst Rev. 2008. https://doi. org/10.1002/14651858.CD000988.pub3.

123. He X, Hu X, Ma X, Su H, Ying L, Peng J, Pan X, Bao Y, Zhou J, Jia W. Elevated serum fibroblast growth factor 23 levels as an indicator of lower extremity atherosclerotic disease in Chinese patients with type 2 diabetes mellitus. Cardiovasc Diabetol. 2017;16(11):77.

124. Belch J, Hiatt WR, Baumgartner I, Driver IV, Nikol S, Norgren L, Van Belle E. Effect of fibroblast growth factor NV1FGF on amputation and death: a randomised placebo-controlled trial of gene therapy in critical limb ischaemia. Lancet. 2011;377(97811):1929-37.

125. Gorenoi V, Brehm MU, Koch A, Hagen A. Growth factors for angiogenesis in peripheral arterial disease. Cochrane Database Syst Rev. 2017:6:CD011741

126. Rigato M, Monami M, Fadini GP. Autologous cell therapy for peripheral arterial disease: systematic review and meta-analysis of randomized, nonrandomized, and noncontrolled studies. Circ Res. 2017;120(81):1326-40.

127. Perin EC, Murphy MP, March KL, Bolli R, Loughran J, Yang PC, Leeper NJ, Dalman RL, Alexander J, Henry TD, et al. Evaluation of cell therapy on exercise performance and limb perfusion in peripheral artery disease: the CCTRN PACE trial (patients with intermittent claudication injected with ALDH bright cells). Circulation. 2017;135(15l):1417-28.

128. Epps JA, Smart NA. Remote ischaemic conditioning in the context of type 2 diabetes and neuropathy: the case for repeat application as a novel therapy for lower extremity ulceration. Cardiovasc Diabetol. 2016;15(1):130

129. Lim SS, Vos T, Flaxman AD, Danaei G, Shibuya K, Adair-Rohani H, Amann M, Anderson HR, Andrews KG, Aryee M, et al. A comparative risk assessment of burden of disease and injury attributable to 67 risk factors and risk factor clusters in 21 regions, 1990-2010: a systematic analysis for the Global Burden of Disease Study 2010. Lancet. 2012;380(98591):2224-60.

130. Kalbaugh CA, Gonzalez NJ, Luckett DJ, Fine J, Brothers TE, Farber MA Beck AW, Hallett JW Jr, Marston WA, Vallabhaneni R. The impact of current smoking on outcomes after infrainguinal bypass for claudication. J Vasc Surg. 2018;68(21):495-502.e491.

131. Bullen C. Impact of tobacco smoking and smoking cessation on cardiovascular risk and disease. Expert Rev Cardiovasc Ther. 2008;6(61):883-95.

132. Morris PB, Ference BA, Jahangir E, Feldman DN, Ryan JJ, Bahrami H, ElChami MF, Bhakta S, Winchester DE, Al-Mallah MH, et al. Cardiovascular effects of exposure to cigarette smoke and electronic cigarettes: clinical perspectives from the prevention of cardiovascular disease section Leadership Council and Early Career Councils of the American College of Cardiology. J Am Coll Cardiol. 2015;66(12l):1378-91.
133. Lane R, Ellis B, Watson L, Leng GC. Exercise for intermittent claudication. Cochrane Database Syst Rev. 2014. https://doi.org/10.1002/14651858. CD000990.pub3.

134. Fokkenrood HJ, Bendermacher BL, Lauret GJ, Willigendael EM, Prins MH, Teijink JA. Supervised exercise therapy versus non-supervised exercise therapy for intermittent claudication. Cochrane Database Syst Rev. 2013;8:CD005263

135. Wing RR, Bolin P, Brancati FL, Bray GA, Clark JM, Coday M, Crow RS, Curtis JM, Egan CM, Espeland MA, et al. Cardiovascular effects of intensive lifestyle intervention in type 2 diabetes. N Engl J Med. 2013;369(2l):145-54.

136. Lane JS, Magno CP, Lane KT, Chan T, Hoyt DB, Greenfield S. Nutrition impacts the prevalence of peripheral arterial disease in the United States. J Vasc Surg. 2008;48(41):897-904.

137. Naqvi AZ, Davis RB, Mukamal KJ. Dietary fatty acids and peripheral artery disease in adults. Atherosclerosis. 2012;222(21):545-50.

138. Campbell A, Price J, Hiatt WR. Omega-3 fatty acids for intermittent claudication. Cochrane Database Syst Rev. 2013;(71):CD003833.

139. Ruiz-Canela M, Estruch R, Corella D, Salas-Salvado J, Martinez-Gonzalez MA. Association of mediterranean diet with peripheral artery disease: the PREDIMED randomized trial. JAMA. 2014;311(41):415-7.

140. Shammas AN, Jeon-Slaughter $\mathrm{H}$, Tsai S, Khalili H, Ali M, Xu H, Rodriguez G, Cawich I, Armstrong EJ, Brilakis ES, et al. Major limb outcomes following lower extremity endovascular revascularization in patients with and without diabetes mellitus. J Endovasc Ther. 2017;24(31):376-82.

141. Freisinger $E$, Malyar NM, Reinecke H, Lawall H. Impact of diabetes on outcome in critical limb ischemia with tissue loss: a large-scaled routine data analysis. Cardiovasc Diabetol. 2017;16(11):41.

142. van Haelst ST, Haitjema S, de Vries JP, Moll FL, Pasterkamp G, den Ruijter HM, de Borst GJ. Patients with diabetes differ in atherosclerotic plaque characteristics and have worse clinical outcome after iliofemoral endarterectomy compared with patients without diabetes. J Vasc Surg. 2017:65(2l):414-421.e415

143. Darling JD, Bodewes TCF, Deery SE, Guzman RJ, Wyers MC, Hamdan AD, Verhagen HJ, Schermerhorn ML. Outcomes after first-time lower extremity revascularization for chronic limb-threatening ischemia between patients with and without diabetes. J Vasc Surg. 2018;67(4I):1159-69.

144. Liang P, Soden PA, Zettervall SL, Shean KE, Deery SE, Guzman RJ, Hamdan AD, Schermerhorn ML. Treatment outcomes in diabetic patients with chronic limb-threatening ischemia. J Vasc Surg. 2018;68(2l):487-94.

145. Indes JE, Pfaff MJ, Farrokhyar F, Brown H, Hashim P, Cheung K, Sosa JA. Clinical outcomes of 5358 patients undergoing direct open bypass or endovascular treatment for aortoiliac occlusive disease: a systematic review and meta-analysis. J Endovasc Ther. 2013;20(41):443-55.

146. Jongkind V, Akkersdijk GJ, Yeung KK, WisselinkW. A systematic review of endovascular treatment of extensive aortoiliac occlusive disease. J Vasc Surg. 2010;52(51):1376-83.

147. Kavanagh CM, Heidenreich MJ, Albright JJ, Aziz A. Hybrid external iliac selective endarterectomy surgical technique and outcomes. J Vasc Surg. 2016;64(5l):1327-34.

148. Ballotta E, Lorenzetti R, Piatto G, Tolin F, Da Giau G, Toniato A. Reconstructive surgery for complex aortoiliac occlusive disease in young adults. J Vasc Surg. 2012;56(61):1606-14.

149. Ye W, Liu CW, Ricco JB, Mani K, Zeng R, Jiang J. Early and late outcomes of percutaneous treatment of TransAtlantic Inter-Society Consensus class C and D aorto-iliac lesions. J Vasc Surg. 2011;53(61):1728-37.

150. Grimme FA, Goverde PC, Verbruggen PJ, Zeebregts CJ, Reijnen MM. Editor's choice-first results of the covered endovascular reconstruction of the aortic bifurcation (CERAB) technique for aortoiliac occlusive disease. Eur J Vasc Endovasc Surg. 2015;50(51):638-47.

151. Schillinger M, Sabeti S, Dick P, Amighi J, Mlekusch W, Schlager O, Loewe C, Cejna M, Lammer J, Minar E. Sustained benefit at 2 years of primary femoropopliteal stenting compared with balloon angioplasty with optional stenting. Circulation. 2007;115(211):2745-9.

152. Laird JR, Katzen BT, Scheinert D, Lammer J, Carpenter J, Buchbinder M, Dave R, Ansel G, Lansky A, Cristea E, et al. Nitinol stent implantation vs. balloon angioplasty for lesions in the superficial femoral and proximal popliteal arteries of patients with claudication: three-year follow-up from the RESILIENT randomized trial. J Endovasc Ther. 2012;19(11):1-9. 